University of Wollongong

Research Online

Faculty of Business - Papers (Archive)

Faculty of Business and Law

$1-1-2017$

Does director trading change the information environment?

Millicent M. Chang

University of Western Australia, mchang@uow.edu.au

Xiaolin Qian

University of Macau

Jing Yu

University of Western Australia

Yvonne See

University of Western Australia

Follow this and additional works at: https://ro.uow.edu.au/buspapers

Part of the Business Commons

Research Online is the open access institutional repository for the University of Wollongong. For further information contact the UOW Library: research-pubs@uow.edu.au 


\title{
Does director trading change the information environment?
}

\author{
Abstract \\ Investigating ASX300 firms for the period 2002-2010, we find that the information content of director \\ trading has a negative relationship with post-trade information asymmetry, but a positive relationship with \\ information efficiency. These results are mainly driven by director purchases rather than their sales, and \\ are stronger in non-executive director trading. Our results are robust to the adoption of IFRS in 2005 and \\ the global financial crisis in 2008. These findings back the claims of insider trading proponents, by \\ showing that director trading plays a crucial role in reducing information asymmetry and in improving \\ information efficiency for stock market participants. \\ Disciplines \\ Business \\ Publication Details \\ Chang, M., Qian, X., Yu, J. \& See, Y. (2017). Does director trading change the information environment?. \\ Australian Journal of Management, 42 (2), 205-229.
}

This journal article is available at Research Online: https://ro.uow.edu.au/buspapers/1394 
Does Director Trading Change the Information Environment?

\author{
Millicent Chang \\ UWA Business School \\ The University of Western Australia \\ Australia \\ millicent.chang@uwa.edu.au \\ +61864882971 \\ Xiaolin Qian \\ Faculty of Business Administration \\ University of Macau \\ Macau SAR \\ xiaolinqian@umac.mo \\ $+85388224750$ \\ Yvonne See \\ UWA Business School \\ The University of Western Australia \\ Australia \\ yvonne.see@uwa.edu.au \\ Jing Yu \\ UWA Business School \\ The University of Western Australia \\ Australia \\ jing.yu@uwa.edu.au \\ +61864881759
}




\section{Does Director Trading Change the Information Environment?}

\section{Abstract}

Investigating ASX300 firms for the period 2002-2010, we find that the information content of director trading has a negative relationship with post-trade information asymmetry, but a positive relationship with information efficiency. These results are mainly driven by director purchases rather than their sales, and are stronger in non-executive director trading. Our results are robust to the adoption of IFRS in 2005 and the global financial crisis in 2008 . These findings back the claims of insider trading proponents, by showing that director trading plays a crucial role in reducing information asymmetry and in improving information efficiency for stock market participants. 


\section{Introduction}

We investigate the effect of trading by directors in their own firm's shares (known as corporate insider trading) on two aspects of the firm's information environment: information asymmetry and stock price informational efficiency. While these legal trades can be conducted for liquidity and diversification reasons, some trades are based on insiders' informational advantage (Seyhun, 1992; Brown, Foo and Watson, 2003). The relationship between insider trading and market efficiency is an important consideration in the enactment and enforcement of regulation on insider trading globally. The abnormal returns following these trades raise residual concerns that the existing regulation that allows insiders to trade in their own firm's shares under certain conditions but requires them to disclose their trading in a timely manner may not be entirely effective. ${ }^{1}$

The pioneering work of economists such as Kyle (1985) and Glosten and Milgrom (1985) is based on the notion that trading by informed traders or insiders is the primary channel by which information is incorporated into price. Advocates for insider trading argue that these insiders possess superior information compared to outsiders. Insider trading therefore enhances the information environment by improving stock price informativeness which in turn results in better resource allocation and improved decision making. For example, Manne (1966), Carlton and Fischel (1983), and Leland (1992) argue that insider trading speeds up the flow of insiders' private information into stock prices, thereby enhancing the information environment by improving stock price informativeness. Empirically, Seyhun (1988), Ke, Huddart and Petroni (2003) and Piotroski and Roulstone (2005) show that trading by insiders incorporates new, private and firm specific information into price. However, Fishman and Hagerty (1992) among others, challenge this view,

\footnotetext{
${ }^{1} \mathrm{~S} 1002 \mathrm{G}(1)$ of the Corporations Act provides the definition of insider and inside information is defined in s1042A. S1043A prohibits insiders acquiring, or disposing of, financial products based on inside information. s205G (4) requires directors to disclose trades in their company's securities within 14 days of the transaction. The ASX Listing Rules 3.19A.1 and 3.19A.2 stipulate that changes of directors' interests must be disclosed within five working days.
} 
contending that insider trading impairs price informativeness and deteriorates stock price efficiency. This is because other traders, aware of the presence of insiders in the market, are discouraged from collecting and trading on information or they may exit the market altogether. Specifically, Bushman, Piotroki and Smith (2005) find that insider trading crowds out private information acquisition by outsiders. Investigating analyst following in countries that impose restrictions on insider trading activities, they however find that the crowding-out effect is concentrated in emerging markets. Similarly, Ausubel (1990) shows that regulation enhances market confidence and wider participation by investors who can now trade on a level playing field. However, Durnev and Nain (2007) report that while stricter regulation deters private information trading, it is less effective in firms with high agency costs. These contradicting points of view highlight the tension between boosting market efficiency (where private information is reflected in stock price) and maintaining market confidence and integrity (to reduce exploitation of investors by better informed parties).

We direct our focus to the interplay between insider trading and the firm's information environment, which includes two important dimensions namely, information asymmetry and stock price informativeness. Information asymmetry occurs when there are informational differences across investors in a market. According to microstructure theory, it exists when informed traders are present in the market. To protect themselves from potential losses when trading with more informed traders, liquidity traders demand wider bid-ask spreads (Kyle, 1985, Glosten and Milgrom, 1985). Corporate insiders represent one such group of potentially informed traders with access to private information. Regulation however prohibits them from trading on price sensitive information although, when they do trade, they are required to disclose their trades to the market in a timely manner. According to Huddart, Hughes and Levine (2001), public disclosure of insider trades hastens price discovery while reducing trading profits. Another dimension of the information environment is information 
efficiency. Information efficiency differs from information asymmetry because it depends on the precision of private information held by corporate insiders. Price informativeness can be useful for corporate decisions. For example, Ferreira et al. (2011) report substitution of board monitoring with price informativeness, because more informative prices make boards more effective and reduce the need for board independence.

In this study, we apply two measures from contemporary microstructure literature, the adverse selection component of the bid-ask spread (adverse selection cost) and the probability of information-based trading $(P I N)$. Similar approaches were taken by Straser (2002), Aslan (2002) and Sidhu, Smith, Whaley and Willis (2008) in their examination of the effects of Regulation FD on information asymmetry. These measures have also been selected because their relationship with insider trading has not been previously examined within the Australian market where such an examination is necessary. Essentially, they reflect the benefits (more efficient prices) and costs (cost of adverse selection) on the information environment.

We use the PIN measure developed by Easley, Kiefer, O'Hara and Paperman (1996) which provides a direct measure of informed trading by analysing information in the trade flow. Many empirical studies examine the role of price informativeness on corporate decisions, using PIN as the proxy for informativeness. For example, Ferreira et al. (2011) find that more informative prices make boards more effective and reduce the need for board independence. Kang and Liu (2010) show that risk-driven information-based trading leads to improved CEO incentives. Chen, Goldstein and Jiang (2007) report that price informativeness affects firm investment policy. The adverse selection cost measure, on the other hand, reflects the cost of trading with informed investors. Where market makers are present, adverse selection cost is designed to capture the cost of compensating the market makers when they trade with informed investors (Goyenko, Holden and Trzcinka, 2009). 
We find that director trades reduce information asymmetry (adverse selection cost) and increase information efficiency (price informativeness). Further analysis reveals that the results can be predominantly attributed to director purchases instead of their sales. In addition, we find that non-executive (independent) director trading, rather than trading by executives, improves the information efficiency of the stock trading environment. Finally, we examine the marginal impact of two significant market events, the adoption of IFRS in 2005 and the global financial crisis in 2008 , on the association between the information content of director trading and the stock trading environment. We find no impact arising from these two events, suggesting that our findings are robust under different market conditions. Therefore, we present a contemporary investigation of the effect of insider trading on two microstructure measures, reflecting information asymmetry and efficiency in the firm's information environment. Further decomposition of the insider trades suggests that insider purchases are more likely to be driven by information than insider sales, since the latter can be motivated by liquidity and portfolio diversification. In addition, non-executives' trades contain more information than executive trades, possibly because the latter are under stricter monitoring and scrutiny. We triangulate the insider trades and measures of information asymmetry with abnormal returns following these trades. This is because the returns to trades signal the private information associated with them, where higher returns are indicative of more informed trades. To the best of our knowledge, our findings have not been documented in the Australian market and our study contributes to the existing literature due to interesting differences between the Australian and U.S. markets.

We contend that the Australian market is an ideal setting to examine the relation between director trading and the stock market information environment for the following reasons. First, the information environment in Australia is managed by the Continuous 
Disclosure Regime ${ }^{2}$, which was introduced in 1994. It aims to reduce information asymmetry between management and investors and also between different types of investors. This is achieved through effective and timely disclosure where firms are expected to inform investors (via the Australian Securities Exchange, ASX) of any market sensitive information when it becomes aware of such information. Brown, Taylor and Walter (1999) report increases in disclosures with the introduction of the Continuous Disclosure Regime, although such changes were limited to small and poorly performing firms. In contrast, when they examined increased enforcement under the same regime, Hsu, Lindsay and Tuttici (2012) find deterioration in analyst forecast dispersion in small firms, likely due to the ban on selective disclosure to financial analysts. Such continuous and periodic reporting frequency affects the firm's information environment where for example, compared to US firms, the majority of Australian firms report earnings on a half-yearly basis.

Second, although insider trading regulation is now commonplace in both developed and emerging markets with Bhattacharya and Daouk (2002) reporting insider trading laws in 87 out of the 103 countries in their study, Australia continues to stand out among common law countries with restrictive insider trading regulation (Beny, 2005). There have also been improvements in enforcement with increases in prosecutions for insider trading in recent time. Such strong regulation and effective enforcement are predicted to alter both the information environment and the trading behaviour of insiders as shown in Brochet (2010) after the Sarbanes Oxley Act (SOX) in the U.S. and Frijns, Gilbert and Tourani-Rad (2008) after the Securities Market Amendment Act (SMAA) in New Zealand.

Last, a persistent finding exists in Australian director trading studies where director sales are reported to have more information content about future firm performance compared to purchases (see for example, Brown, Foo and Watson, 2003). This is in contrast to the more

\footnotetext{
${ }^{2}$ The Continuous Disclosure Regime is regulated in Chapter 6CA (s674-678) of the Corporations Act and through the ASX Listing Rules (Chapter 3).
} 
prevalent finding that purchases have comparatively more information content (Lakonishok and Lee, 2001; Fidrmuc, Goergen and Renneboog, 2006). In Hong Kong however, abnormal returns are earned on both insider purchases and sales (Cheuk, Fan and So, 2006) Fidrmuc, Korczak and Korczak (2013) also find that in countries with stronger governance and enforcement mechanisms, insider purchases are more informative. While there is general agreement that insider purchases signal the firm's favourable future prospects, the information associated with sales is less clear. Insider sales can signal negative information about the firm's prospects, but they can also be conducted for liquidity, rebalancing or diversification, which are less informative. With the contrasting information content between purchases and sales, it is interesting to investigate whether the insider purchases or sales in Australia have stronger effect on the information environment.

The time period covered in our study traversed two significant market-wide events, the adoption of IFRS in 2005 and the global financial crisis in 2008, which had the potential to change the firm's information environment. Daske, Hail, Leuz and Verdi (2008) and Barth, Landsman and Lang (2008) suggest that reporting under IFRS increases transparency resulting in higher quality financial reporting. There is also a counter-contention that IFRS would bring little change to accounting quality as Australian domestic standards were similar to IFRS and being a common law country, it has strong investor protection (Jeanjean and Stolowy, 2008). However, Brochet et al (2013) report that following IFRS adoption by UK firms, there was a reduction in private information benefits in the form of lower abnormal returns with insider purchases only. Another important event that could potentially influence the relationship between director trading profitability and stock information environment was the global financial crisis in 2008. Panic among investors during the crisis impaired market liquidity and increased the adverse selection effect of director trading (Brunnermeier \& Pedersen, 2009). Directortrading can be more informative when the trading of other investors 
becomes rare in the post-crisis period due to the lack of confidence. We therefore take a step further to look at whether these significant market events had any influence on the relationship between director trading and the stock information environment. Consistent with previous studies, we find that the adoption of IFRS in 2005 and the global financial crisis in 2008 had significant impacts on the information environment, but neither event had a significant moderating effect on the association between the director trading and the stock information environment. Thus, our findings are robust under different market conditions.

This study contributes the literature in several ways. First, our results highlight the effects of director trading on the information environment. In particular, trading by directors reduces information asymmetry and improves information efficiency for stock market participants. Second, we mark the importance of the types of director trades (purchase or sale) and the roles played by the directors (executives or non-executives) in assessing the effect on the information environment. We thereby provide additional information for regulators and monitors of the capital market, which helps improve the efficiency of insider trading regulation and disclosure requirements, leading to better investor protection. Finally, global events such as the introduction of International Financial Reporting Standards (IFRS) and the global financial crisis (GFC) did not impact on the relation between insider trade returns and the firm's trading environment, suggesting it is robust to different time periods and market conditions. Our study urges a more comprehensive documentation of director trading activity so that we can better understand the impact and effect of these activities on many aspects of firm value and trading participation.

The remainder of the study is as follows. Section 2 presents the review of the literature and hypothesis. Section 3 provides data, method and descriptive statistics. Section 4 and Section 5 give the results and conclusions, respectively. 


\section{Prior work and hypotheses}

\subsection{Prior work on the relation between insider trading and information environment}

Information-driven trading by corporate insiders is a double-edged sword; it can potentially both benefit and harm the firm's information environment. Such informed trading affects information asymmetry because corporate insiders have access to information unavailable to outside investors. Insiders also have the opportunity to extract private benefits by trading on this information. With these trades, insiders' private information is incorporated into the stock prices, and thereby insider trading can make stock price more informative.

Proponents of insider trading such as Manne (1966) and Carlton and Fischel (1983) contend that insider trading is beneficial because it improves the firm's information environment. They suggest that insiders are the most informed parties about their firm's future prospects. As they trade, their private information is incorporated into stock prices in a more timely and accurate fashion, and thus their transactions improve the firm's information efficiency. In contrast, others believe that insider trading exacerbates the information asymmetry faced by outside market participants, thereby discouraging investment (Ausubel, 1990) and reducing market liquidity (Leland, 1992). Further, Fishman and Hagerty (1992) argue that insider trading harms the information environment as it deters outside market participants from collecting and trading on information because insider trading squeezes gains available to outsiders.

It is generally expected that insiders are motivated by trading profits based on their informational advantage regarding the firm's prospects. Models of informed trading such as Kyle (1985) and Grossman and Stiglitz (1980) assume that an insider is informed in every period, making it ideal to trade in every period. However, realistically, corporate insiders may not possess equal amounts of superior information all the time. In fact, they are presumed to have more informational advantage during certain times such as prior to earnings 
announcements or takeover announcements (see Ke, Huddart and Petroni, 2003; Agrawal and Nasser, 2012). Insider trades are also relatively infrequent, due to the trading restrictions imposed on them by firm trading policies. Kyle's (1985) theoretical model demonstrates that informed trading worsens the information environment as it leads to wider spreads due to the adverse selection problem between informed traders and other market participants. In Glosten and Milgrom's (1985) model, when traders with superior information are present, there is a widening of the bid-ask spread. Similarly, Copeland and Galai (1983) show that the bid-ask spread is positively related to price level and return variance and negatively with market activity and depth.

Empirically, the effect of insider trading on the information environment has been examined using various proxies for the information environment, with mixed results. Using the bid-ask spread, Chung and Charoenwong (1998) find that in firms with a greater proportion of insider trading, market makers protect themselves with wider spreads. Although Fernandes and Ferreira (2009) report that enforcement of insider trading laws improves stock price informativeness, the effect is concentrated in developed markets. Piotroski and Roulstone (2004) find an inverse relationship because these trades contain firm specific information. Khan et al (2011) find no change in spread with insider sales for NASDAQ-100 stocks. However, there are liquidity increases with active informed trading (Cornell and Sirri, 1992) while there is an increase in effective spread during permitted insider trading periods (Bettis et al. 2000). Cao et al. (2004) report small and transitory increases in the effective spread with insider trading activities, although Cheng, Firth, Leung and Rui (2006) show wider spreads and lower depths on insider trading days compared to other days.

Clarke and Shastri (2000) report no relationship between insider trades and PIN while Aktas, de Bodt and van Oppens (2008) show changes in relative order imbalance as a result of insider trading, indicative of faster price discovery on these days. Huddart and Ke (2007) 
use six information asymmetry proxies including institutional ownership, analysts following, book-to-market ratio, frequency of firm reporting losses, firm reporting $\mathrm{R} \& \mathrm{D}$ expenditure and abnormal returns over previous earnings announcements. Overall, they find that the first four proxies do not reflect information asymmetry while R\&D expenditure and abnormal returns do so for models of informed trading.

\subsection{Hypotheses development}

Considering the contradictory findings of the effects of insider trades on the information environment using various proxies, we re-examine the effect on insider trading activity on two interconnected contemporary measures of the information environment: adverse selection cost and the probability of informed trading (PIN) in the Australian market, a developed market with restrictive insider trading laws and effective enforcement. We relate the returns from insider trades, instead of the trades themselves to cost of adverse selection and the probability of informed trading because the information content of the trades is reflected in the post-trade returns. If insiders trade for private information, they should earn superior returns, i.e. the stock's abnormal return is positive (negative) after informed insider purchase (sale).

The adverse selection cost is an indirect measure of the cost of information asymmetry that together with order processing costs, inventory costs and competition make up the bid-ask spread. We directly use the cost of adverse selection instead of the bid-ask spread to eliminate the cross-sectional variation in the other components. Theoretically (see Kyle, 1985; Copeland and Galai, 1983; Glosten and Milgrom, 1985), a positive relationship is predicted between informed trading and information asymmetry. In the context of regulatory changes, Frijns, Gilbert and Tourani-Rad (2008) report a decrease in information asymmetry (spread) as a consequence of a change to the insider trading regulation in New 
Zealand. However, Budsaratragoon, Hillier and Lhaophadchan (2012) caution that when insider trading regulations from developed economies are adopted in emerging ones such as Thailand, these regulations are ineffective as insiders continue to earn excess returns by exploiting their privileged information.

Directors as a group of informed traders, trade on their private information, and this may increase information asymmetry between corporate managers and outside investors. Therefore, the insider trading activity will increase the adverse selection cost and worsen the information environment. In contrast, informed directors may deter informed trading by other non-insiders and level the playing field between informed and uninformed traders (Fishman and Hagerty, 1992). As a result, adverse selection cost can be reduced due to director trading. These competing hypotheses are stated as:

H1: Director trading activity increases information asymmetry.

Hla: Director trading activity decreases information asymmetry.

Another dimension of the information environment is information efficiency. Information asymmetry and information efficiency are not identical concepts because the latter depends on the precision of private information held by corporate directors. Information efficiency increases the price informativeness and is useful for corporate decisions. For example, Ferreira et al. (2011) find the informed stock price increase the board efficiency and reduces the need for board independence. Kang and Liu (2010) find the risk-driven information-based trading leads to improved CEO incentives.

One would only observe a significant impact of director trading on information efficiency if directors are exposed to precise private information and such information is not yet disclosed to other market participants. Therefore, the informed director trading can be 
conducive to the information efficiency of stock trading environment (Fishman and Hagerty, 1992). These two hypotheses are stated as:

H2: $\quad$ Director trading activity increases information efficiency.

H2a: Director trading activity decreases information efficiency.

Next we investigate the insider motivation hypothesis. Insiders have different incentives for buying and selling shares, so we examine the effects of director purchases and director sales on the cost of adverse selection and PIN separately. The motivation for insider purchases is typically private information while for sales, the motivation could also be noninformationally-based such as liquidity and diversification. In other words, insider purchases are expected to provide a clearer signal of its informational content than insider sales. Some research on insider motivations for trading supports these contentions. For example, Lakonishok and Lee (2001) and Jenter (2005) both find that sales are not informative about future firm performance, and Lakonishok and Lee (2001) specifically report that only insider purchases in small firms predict firm future returns. Similarly, Seyhun (1992) shows that sales, especially in large firms, have lower information content. In addition, Fidrmuc, Goergen and Renneboog (2006) argue that the market's reaction to insider purchases and sales is a function of ownership levels held by the insiders and other block holders due to the effect of the latter's monitoring on information asymmetry.

In Australia, however there is the persistent and puzzling finding that insider sales have more information content than purchases (Brown et al, 2003, Chang, Hillman and Watson, 2005). Therefore abreakdown into purchases and sales is crucial when examining the Australian market. Hodgson and van Praag (2006) suggest a reason for this finding is the proportional difference in insider trading for non-information reasons between U.S. and Australian insiders as a result of their equity related compensation. In addition, insider trades 
in Australian studies are made up of trades by corporate directors only, while with the U.S. definition of insider, the reported trades include trades by shareholders with holdings of five percent or more. These shareholders in Australia (known as substantial shareholders) report their trades under a different regulation.

In light of the reported disparity in information content between director purchases and sales in Australian firms as in Brown et al (2003), we predict that the trading direction matters in the relationship between director trading and information environment. Therefore the hypotheses are stated as below:

H3: Director purchases have stronger effects on the information environment than director sales.

H3a: Director sales have stronger effects on the information environment than director purchases.

Recent studies recognise that insiders are not a homogenous group. They play various roles within the firm and therefore have access to different types of firm specific information (Knewtson and Nofsinger, 2014). In addition, depending on their roles, insiders are subject to different levels of scrutiny and have different incentives to trade on private information. While executive directors are responsible for the running and management of the firm, nonexecutive directors are expected to be independent of the firm and to monitor the activities and decisions of executive directors. An examination of the returns to insider trades reflects the interaction between the information on which trades are based (information hierarchy hypothesis) and the scrutiny hypothesis (willingness to capitalise on the information, given the scrutiny and visibility of the insider).

Top-level insiders have access to more value-relevant information, as indicated by their trading activities (Lin and Howe, 1990; Nunn, Madden and Gombola, 1983; Seyhun, 
1986). However, Fidrmuc et al (2006) did not find a relationship between insider position and subsequent returns, possibly due to the more intense scrutiny on senior management. Piotroski and Roulstone (2007) and Korczak, Korczak and Lasfer (2010) both consider the incentives to take advantage of private information and the impediments created by legal and reputational risks. ${ }^{3}$ In a study of late reported insider trades, Chang and Watson (2015) show that purchases by all insiders in small firms signalled future positive returns while only sales by executives in large firms predicted future negative returns. Ravina and Sapienza (2010) compare the trading returns of independent directors and executive directors. They find only small differences in their purchases, indicating that they maybe trading on similar information. Similarly, Gray, Harymawan and Nowland (2014) report that political and government connections on corporate boards have no particular effect on shareholder wealth in Australian firms.

Therefore, there are inconsistent findings on the information possessed by different types of directors in the firm together with the effect of such information on their trading patterns. It is possible that executives have more material private information than nonexecutive directors, but executives are under stricter scrutiny than non-executive directors. If non-executive directors trade relatively freely, the information content of non-executive director trading can be richer than that of executive director trading. On the other hand, nonexecutive directors are responsible for monitoring the activities of the board and may be less likely to trade opportunistically.

H4: Non-executive director trades have stronger effects on information environment than executive director trades. .

\footnotetext{
${ }^{3}$ Piotroski and Roulstone (2007) analyse the non-linear relationship between insider trading and next year's earnings surprise. They report an increase in the likelihood of trading with the earnings surprise. However, this relationship does not hold in the case of extreme news.
} 
H4a: Executive director trades have stronger effects on information environment than non-executive director trades.

\section{Data and Variable Construction}

In this section, we describe the data sources and variable construction employed to test our predictions. Our sample period starts from the fiscal year ending on or after July 2002 through to June 2010. We winsorise variables at the top and bottom one percent of the distribution, to eliminate the effect of outliers.

\subsection{Measuring the information content of director trades}

We compile our sample by collecting director trade information from Appendix 3Y Change in Director Interest announcements on Morningstar DatAnalysis Premium. The sample is limited to ASX300 firms on the basis of market capitalisation at the beginning of each year. This includes the largest and more liquid firms with considerable trading by directors. To ensure no bias in the chosen sample, we conducted a pilot study and collected director trade information for the Top 500 firms by market capitalisation (based on the All Ordinaries Index) in the 2010 fiscal year. The director trades in ASX300 firms account for approximately $70 \%$ of the sample, assuring us that substantial director trading activity occurs in these firms.

From Morningstar DatAnalysis Premium, director trade information including director name, director position, trade and report dates, number of shares traded, transaction price and the direction of trade (purchase or sale) are obtained. We exclude any trades due to reasons such as participation in dividend reinvestment plans, bonus issues, rights issues, employee share purchase schemes, option conversions, convertible note conversions and 
exercise of performance rights. This filtering results in an initial sample of 21,973 trades over the nine-year period.

On the basis of the director trade information, we use the (implied) profitability of director trades as the proxy for the information revealed through director trades. In other words, we expect profitable director transactions if corporate directors utilise their private informational advantage in their trades. Following prior literature (Ahmad et al. 2004; Friederich et al., 2002), the director trade profitability $(C A R)$ is computed as the cumulative market-adjusted over the event window [0, 120], where day 0 represents the director transaction date. For ease of interpretation, we multiply $C A R$ by -1 for director sales. We use the profit from these trades, instead of the trades themselves, because their information content is reflected in the post-trade returns. If insiders trade based on private information, they should earn superior profits, i.e. $C A R$ is positive (negative) after informed insider purchase (sale), and a higher CAR indicates the insider has more informational advantage.

In Table 1, we note that the mean value of $C A R$ is 0.0242 and the median value is 0.0178. The unreported results show that the mean is significantly different from zero, suggesting that director transactions are profitable on average, reassuring us that director trade profitability is a good proxy for the information content of director trades.

$<$ Please insert Table 1 here>

\subsection{Measuring Firm Information Environment}

Measures of a firm's information environment in previous studies have been marketoriented or related to firm characteristics. We chose market-oriented measures because they are less subject to managerial discretion and therefore are more exogenous than measures based on firm characteristics. For example, managers may time or distort disclosures 
depending on their trading intentions (Rogers, 2008). Firm characteristics such as firm size and book-to-market ratio are simultaneously affected by determinants other than information asymmetry. Analyst coverage and institutional ownership estimate the external information search, but the data maybe too static to observe the immediate impact of insider trading.

Market-oriented measures, on the other hand, directly gauge the informational impact of insider trades and are less subject to alternative explanations. Recent studies deploy similar proxies to examine the quality of a firm's information environment. For example, Haggard, Howe and Lynch (2015) use spreads and other illiquidity ratios as proxies for information asymmetry and interpret a decrease in the illiquidity measures following non-recurring changes in earnings as an improvement in informational transparency. Chen, Goldstein and Jiang (2007) use PIN to assess the effect of price informativeness on firm investment policy. Some studies use daily measures, such as Amihud's (2002) ratio and $C 2$ in Llorente et al. (2002), but these measures are calculated from daily returns and the aggregated daily trading volume and thus may overlook some information incorporated in high-frequency data. Given our access to intraday data, we are able to calculate an adverse selection measure and PIN that utilize all relevant transactions and quotations, which should accurately reflect the information revealing process though trades. Nonetheless, the PIN developed by Easley et al (1996) and Easley, Hvidkjaer and O'Hara (2002) is based on assumptions that independent information events occur daily and informed traders act on these events on the day they occur. In reality, these assumptions may not hold. In addition, PIN may also be correlated with other variables. For example, in a high information asymmetry stock, the adverse selection effect could show up as low trading volume and wide spreads. If PIN is correlated with some other factor, which in turn correlated with information asymmetry, then PIN will be correlated with the probability of informed trading; although information asymmetry is not identical to informed trading (Benos and Jochec, 2007). Mohanram and Rajgopal (2006) confirm that 
PIN is not a risk factor that is priced in a cross-section of returns. Duarte and Young (2009) consider the issue of whether PIN is priced because it is associated with information asymmetry or other liquidity factors. They show that the PIN component related to information asymmetry is not priced, unlike its other component associated with liquidity, which is. Taking another perspective, Bollen, Smith and Whalley (2004) develop a simple and parsimonious bid-ask spread model that takes into account the minimum price tick, order processing costs, inventory holding costs, adverse selection costs and competition. An innovation of this model was that the probability of informed trading could be identified, thereby bypassing some of the issues with information asymmetry in the previously mentioned models.

Various proxies have been used to study the relationship between insider trades and information environment and the results are understandably mixed. For example, Chung and Charoenwong (1998) find no change in spread or depth on insider trading days. Cornell and Sirri (1992) find liquidity increases with active informed trading, while Bettis et al. (2000) find an increase in effective spread during permitted insider trading periods. Cao et al. (2004) report small and temporary increases in the effective spread for insider trading activities, although Cheng, Firth, Leung and Rui (2006) show wider spreads and lower depths on insider trading days than on other days. Clarke and Shastri (200) report no relationship between insider trades and PIN. Huddart and Ke (2007) use six information asymmetry proxies (institutional ownership, analyst following, market to book ratio, loss frequency, R\&D expenditure and abnormal return over past earnings announcements) when they investigated the relationship between insider trades and the firm's information environment. They concluded that either the first four are not good proxies for information asymmetry or else, the models of informed trading cannot be applied to corporate insider trading. The variability 
in these results recommends both careful selection of the appropriate proxy for information asymmetry and the sensitivity of the insider trades measure.

Drawing on prior literature and to demonstrate the trade-offs expected with director trading, we measure two dimensions of the firm's information environment using marketbased measures estimated from stock intraday transactions data. The advantage of using market-based measures is that these measures directly reflect the outcome of information asymmetry and information efficiency improvements resulting from director transactions. The market-based measures reflect the cost and benefit for investors as a result of the director trades. The proxy for firm information asymmetry is adverse selection cost while the proxy for corporate information efficiency is the probability of informed trading $(P I N)$ measure. We estimate these two information proxies using stock intraday transactions data drawn from Thomson Reuters Tick History (TRTH) database.

The classic market microstructure literature suggests that adverse selection cost and inventory cost are two major determinants of stock transaction costs. In this analysis, the computation of adverse selection cost for each trade follows the construct used in Goyenko, Holden, and Trzcinka (2009). For each trade $i$, we compute the corresponding adverse selection cost measure as follows:

$$
5 \text { - Minute Adverse Selection } \operatorname{Cost}_{i}=2 \times D_{i} \times\left(\ln \left(M_{i+5}\right)-\ln \left(M_{i}\right)\right)
$$

where $M_{i+5}$ denotes the midpoint of prevailing quote prices five minutes after trade $i$ and $M_{i}$ is the midpoint of prevailing quote prices for trade $i ; D_{i}$ denotes the trade direction which takes the value of one if trade $i$ is a buy transaction and takes the value of negative one if it is a sell transaction. Given that the TRTH database does not provide trade directions, we use Lee and Ready (1991) algorithm to assign trade directions. The daily adverse selection cost measure is equal to the value-weighted average of intraday adverse selection costs across all trades. 
The measure of information asymmetry used in subsequent empirical analysis is computed as the average of daily adverse selection costs in the event window $[0,120]$ where day 0 is the date of director transaction, scaled by daily average adverse selection costs computed over the window [-120, -21] (denoted as adjAdverse). As shown in Table 1, the unscaled daily average adverse selection cost (Adverse) ranges from 0.0003 to 0.0106 , with a mean value of 0.0024 and median of 0.0018 . These statistics obtained from Australian stocks are largely comparable to those shown in the U.S studies. To reflect the rise in information asymmetry in the event window, we apply scaling to the Adverse variable.

On the assumption that firm information efficiency is reflected by how quickly superior information is impounded into stock prices, we use the PIN measure developed by Easley, Kiefer, O'Hara and Paperman (1996) as the proxy for information efficiency. This measure is based on a structural market microstructure model which consists of three participants, noise traders, informed traders and a market maker. Informed traders will trade on their private information when they believe the information is not publicly known. Thus, PIN directly captures the private information incorporated into stock price and measures the informativeness (Ferreira et al., 2011; Kang and Liu, 2010; Chen et al., 2007). The PIN measure in the event window $[0,120]$ relative to director transaction date is estimated in two steps: we first identify the trades on each trading day as a buy or sell transaction; in the next step, we use the algorithm in Easley, Kiefer, O'Hara and Paperman (1996) to estimate PIN over 120 days from the day of the transaction. Again, the raw PIN measure is scaled by its estimate obtained from the $[-120,-21]$ window in order to control for the level of information efficiency.

Table 1 summarises the distribution of variables. In our sample, adjAdverse ranges from 0.4223 to 2.3959 , with a mean of 1.0237 . The mean and median values of PIN are 
0.1818 and 0.1715 , respectively, similar to the PIN statistics documented for the NYSE stocks.

\subsection{Other variables}

We also control for a number of firm-level variables in our study. These control variables are turnover (Turnover), return volatility (Volatility), book-to-market ratio (BM), firm size (Size), and resource and financial industry dummy variables. The information on control variables is collected from Thomson Reuters Datastream database and is matched with trade data from DatAnalysis Premium.

Specifically, turnover is defined as log of number of shares traded over the previous year. Return volatility is the log of the standard deviation of daily returns over the previous year. To control for other unobservable firmcharacteristics, we also include book-tomarket ratio and a firm size variable. The book-to-market ratio is defined as the book value of equity divided by the market value of equity. Size is equal to the log of market value of equity at the end of the previous year. The urnover variable, Turnover, exhibits a symmetric distribution, evident from a mean of 5.545 and a median of 5.696. The mean values of Volatility and $B M$ are 0.0212 and 0.5743 , respectively. The mean and median of Size are 21.393 and 21.267, suggesting that our sample firms are relatively large.

Finally, we control for two industry indicator variables. With the high proportion of resource firms in the Australian market together with more pronounced information asymmetry issues in this sector, a resource sector indicator variable is included. Resource takes on a value of one when the firm is in the resources sector and zero otherwise. As many of the largest firms in the Australian market are financial institutions which are subject to additional regulatory scrutiny, we include Financials (which takes the value of one if a firm operates in the financial sector, and zero otherwise), an indicator variable to account for this 
effect. As shown in Table 1, it is not surprising that approximately 17\% of the companies are in the resources sector while about $25.6 \%$ of the sample firms are in the financial sector. These statistics confirm the necessity to control for these two industries in our empirical analyses.

\subsection{Pearson correlation of variables}

There are several noteworthy observations in Table 2 which reports the Pearson correlation coefficients among all of the variables in this study. First, the measure of the information content of insider trading, $C A R$, is negatively and significantly related to postevent adjusted adverse selection cost (adjAdverse) but positively and significantly related to post-event adjusted PIN (adjPIN). This implies that informative director trading reduces information asymmetry between corporate directors and outside investors and promotes the information efficiency through the trading process. Second, while the correlation coefficient between adjAdverse and adjPIN is 0.011 , this coefficient is statistically insignificant. The implication from this observation is that although both measures capture information-based stock trading activities, they reflect different dimensions of the firm's information environment. Finally, except for the strong correlation between Turnover and Size (the correlation coefficient is 0.711 ), all other correlation coefficients among variables are only moderate, alleviating the multicollinearity concern in our empirical analysis.

$<$ Please insert Table 2 here $>$

\section{Empirical results}

\subsection{Main analysis}


There has been much debate in the literature on the benefits and costs of insider trading on the information environment. Opponents of insider trading argue that when directors trade on their privileged private information, such trading increases the information asymmetry between corporate insiders and outside investors and worsens the information environment of stock trading. However, others argue that director trading can facilitate the incorporation of private information into stock price through their informed trading activities, leading to more efficient stock prices. In this empirical investigation, we systematically look at the effects of informed insider trading on both the information asymmetry and information efficiency of the stock trading environment.

The main analysis is carried out by estimating the following Ordinary Least Squares (OLS) regression model specification:

$$
\begin{aligned}
\text { InfoEnv }= & \alpha+\beta_{1} C A R+\beta_{2} \text { Turnover }+\beta_{3} \text { Volatility }+\beta_{4} B M+\beta_{5} \text { Size }+ \\
& \beta_{6} \operatorname{Re} \text { source }+\beta_{7} \text { Financials }+ \text { Year dummies }
\end{aligned}
$$

where InfoEnv alternatively represents adjusted adverse selection cost(adjAdverse) or adjusted PIN (adjPIN) over the event window $[0,120]$ relative to the director transaction date. CAR is the cumulative market-adjusted stock return over the event window $[0,120]$ relative to the director transaction date. The list of control variables includes stock turnover (Turnover), stock return volatility (Volatility), book-to-market ratio (BM), firm size (Size), the resource sector dummy variable (Resource) and the financial sector dummy variable (Financials). Year dummies are also included to control for the time variations in the information environment measures over the years.

We first examine the effect of informed director trading on the cost of adverse selection, adjAdverse, by estimating the baseline regression and reporting the results in model (2) of Table 3. We observe a consistently strong negative association between returns from trades and post-director trade adverse selection cost. The coefficient on CAR is -0.178 
$(t$-value $=-4.71)$. In model $(1)$, the coefficient on $C A R$ is $-0.168(t$-value $=-4.24)$ and in model (3), the coefficient on CAR becomes $-0.133(t$-value $=-4.41)$ after controlling for other stock and firm characteristics including year dummies. The overall results indicate that informative director trading (measured by director trading profitability) reduces the information asymmetry between informed traders and uninformed traders and supports hypothesis H1a. The interpretation is plausible if informed directors deter the informed trading from other non-directors and therefore level the playing field between informed and uninformed traders (Fishman and Hagerty, 1992).

The selected control variables appear to capture the expected signs. Taking the full sample results in model (3) for example, we find a positive relationship between post-director trading adverse selection cost and stock turnover, indicating that informed traders tend to be able to hide their traders better in actively traded stocks. In addition, the positive coefficient on Volatility suggests that stocks with high information uncertainty experience an increase in adverse selection cost following director trading. Finally, we note that post-director trading adverse selection cost increases with book-to-market ratio and declines if firms operate in the resources sector.

\section{$<$ Please insert Table 3 here $>$}

Next, we turn to the effect of director trading on the information efficiency of stock trading. It is argued that information asymmetry and information efficiency are not identical concepts because the latter depends on the precision of private information held by corporate insiders. One would only observe significant impact of director trading on information efficiency if directors are exposed to precise private information and such information is not yet disclosed to other market participants. In Table 4, we document a strong positive relationship between director trading profitability and information efficiency. Without 
controlling for any other variables, the coefficient of $C A R$ is $1.890(t$-value $=2.02)$ in model (1). The magnitude and statistical significance remains similar after the incorporation of all controls including year dummy variables. These results are in line with the notion that informed director trading is conducive to the information efficiency of stock trading environment (Fishman and Hagerty, 1992), and supports hypothesis H2.

\section{< Please insert Table 4 here>}

We further disaggregate insider trades into purchases and sales and report the results in Table 5. In models (1) and (2), the results show a negative relation between $C A R$ and adjAdverse for director purchases but a positive relation between $C A R$ and adjAdverse for director sales, suggesting that informed director purchases have distinct effects from director sales. On average, director purchases mitigate the information asymmetry faced by uninformed liquidity traders while director sales aggravate the problem.

Next, we examine whether the effect of director trading on information efficiency is related to the direction of director trades by partitioning our sample into purchases sales. The results in models (3) and (4) of Table 5 show a positive and significant coefficient on CAR on the director purchases subsample (which accounts for $87 \%$ of the full sample) with an insignificant coefficient in the director sales subsample (13\% of the full sample). Consistent with the information asymmetry effect, it appears that only director purchases help to promote the informational efficiency of the stock trading environment by impounding private information into stock prices, supporting hypothesis H3a.

< Please insert Table 5 here> 
As stated in $\mathrm{H} 4$ and $\mathrm{H} 4 \mathrm{a}$, there could be an information hierarchy between executive and non-executive directors. Executives are under stricter scrutiny while non-executive directors can trade relatively freely. Therefore, the information content of non-executive director trading can be richer than that of executive director trading. After splitting all director trades into executive and non-executive trades in Table 6, it is clear that nonexecutive trades are more prominent in our sample, which accounts for approximately $73 \%$ of the full sample, consistent with the low level of liability associated with non-executive trades.

By regressing adjusted adverse selection cost on the director trading profitability measure, $C A R$ on both executive trades and non-executive trades subsample, we find negative and highly significant coefficients on $C A R$ across both subsamples in models (1) and (2), while the coefficients show a stronger effect in the non-executive trades subsample. However, the effects of executive trades versus non-executive traders are remarkably distinct on information efficiency, as shown in models (3) and (4). We note an insignificant coefficient on $C A R$ on executive trades subsample while a positive and significant coefficient on $C A R$ on non-executive trades subsample. These results collectively suggest that it is the information distilled from non-executive trades that has a stronger influence on the informational efficiency of the stock trading environment. Our findings support the argument that insiders should not be treated as a homogenous group of informed traders and the different levels of scrutiny surrounding executives and non-executive director trading causes them to trade differently on the information they have obtained.

< Please insert Table 6 here>

\subsection{Robustness tests}


We address several concerns about our empirical design in this section. Because of the overlap in the event window we use to compute director trading profitability and two information environment variables, it is possible that the observed relationship between the two sets of variables are simultaneously driven by the same but unobservable firm/stock characteristics. To mitigate this concern, we re-estimate the two information proxies using an alternative event window [121, 240] relative to director transaction date. The related results are reported in models (1) and (2) of Table 7. We find that the coefficient of $C A R$ is $-0.309(t-$ value $=-7.56)$ when new adjusted adverse selection cost is used as dependent variable, while the coefficient of $C A R$ is $1.873(t$-value $=1.80)$ when new adjusted PIN is the dependent variable. The results are qualitatively the same as the previous findings.

In addition, it is argued that buy-and-hold returns are more efficient than cumulative abnormal returns if the event window tends to be long. To ensure the robustness of our results, we re-estimate the measure of director trading profitability as the buy-and-hold abnormal returns over the event window $[0,120]$ relative to director transaction date. In models (3) and (4), we find results consistent with those reported in Table 3 and Table 4.

\section{$<$ Please insert Table 7 here $>$}

It should be noted that two significant market events occurred during our sample period from 2002 to 2010 . The prominent events include the adoption of International Financial Reporting Standards (IFRS) in Australia in 2005 and the adverse economic impact of the global financial crisis in 2008. In Table 8, we take a further step and examine whether these important market events have any influence on the relationship between director trading profitability and the stock trading environment. Specifically, to evaluate the effect of IFRS on director trading profitability, we introduce an additional dummy variable, IFRS, into the 
baseline regression model (2). This dummy variable takes a value of one if the observation is on or after fiscal year 2005, and zero otherwise. In Table 8, including the dummy IFRS and the interaction term between $I F R S$ and $C A R$, we observe a negative and significant coefficient on IFRS in model (1) when adjusted adverse selection cost is used as dependent variable, but an insignificant coefficient on IFRS in model (3) when adjusted PIN is used as dependent variable. These results are consistent with prior literature which finds evidence of the IFRS adoption improving financial transparency and thereby reducing information asymmetry with outside investors (Daske et al., 2008; Barth et al., 2008). However, we find no significant effect of the interaction terms in either model (1) or model (3), indicating that there is no distinguishable effect of the IFRS adoption on the relationship between director trading profitability and the stock trading information environment. This indicates that the information available to insiders under IFRS does not affect their trading returns and is consistent with the superior information held by these insiders, regardless of the introduction of IFRS. This finding mirrors Straser (2002) where there was no change in cost of adverse selection or probability of informed trading with the introduction of Regulation FD.

We further examine the impact of global financial crisis on the association between informative director trading and stock trading information environment in models (2) and (4) of Table 8. Empirically, we incorporate a global financial crisis dummy variable $(G F C)$ and its interaction with $C A R$ into the baseline model. The $G F C$ dummy variable takes a value of one if the observation is in year 2008, and zero otherwise. Interestingly, in model (2), we find a negative coefficient on $G F C$ when adjusted adverse selection cost is used as dependent variable. It implies that the post-director trading information asymmetry declines in the year of global financial crisis. Our interpretation is that the widespread global financial crisis directs investor attention to market-wide information and therefore alleviates the impact of firm-specific information. More importantly, we find that the coefficients of the interaction 
between $G F C$ and $C A R$ are statistically insignificant in models (2) and (4), suggesting that global financial crisis has no marginal effect on the relation between the information content of director trading and stock trading information environment. Overall, results in Table 8 suggest that our finding on the impact of director trading is robust to different market conditions.

\section{$<$ Please insert Table 8 here $>$}

\section{Summary and Conclusion}

In this study we investigate an important and much debated issue about the empirical effect of director trades on firm information environment. Using adverse selection cost and probability of informed trading as proxies for two important but distinct dimensions of information environment, we document several interesting results.

First, on a sample of the 300 largest Australian firms for the period 2002-2010, the information content of corporate insider trading, measured by director trading profitability, exhibits an inverse relation with post-director trading information asymmetry between corporate directors and outside investors, measured by adjusted adverse selection cost. This suggests that informative director trading decreases information asymmetry. We also document a positive relationship between director trading profitability and post-director trading information efficiency, measured by PIN. This finding is consistent with director trading facilitating the improvement of stock price informativeness and the information efficiency of stock trading environment. Further analysis reveals that the above results are mainly driven by director purchases instead of director sales.

We also investigate the differential effects of executive and non-executive director trading on the stock trading information environment. Though our results suggest no distinct impact of executive and non-executive director trading on the information asymmetry aspect 
of the stock trading environment, it appears that non-executive director trading promotes information efficiency. Finally, we examine the marginal impact of significant market events, the adoption of IFRS in 2005 and the global financial crisis in 2008, on the association between the information content of director trading and the stock trading environment but document no significant impact from these events.

This study supports the viewpoint that trading by directors is crucial for reducing information asymmetry and improving information efficiency for stock market participants. Further, it is also important to understand how the types of director trades and the roles of the directors affect information asymmetry and information efficiency differently. Such trading activity has to be effectively regulated and monitored to ensure transparency and confidence in capital markets. The objectives of director trading regulation and disclosure requirements are for investor protection, that is, to ensure investors operate in an informed and orderly market. Up to date and complete information about changes in the shareholdings of directors is vital to investors and the market in general to comprehend the effect of these changes on firm value. If such information is not available or incomplete, i.e., when there is a lack of transparency, then investors may not be able to make savvy decisions on their trading. The 2008 Australian Share Ownership Study conducted by the ASX showed that $41 \%$ of adult Australians owned shares and of these, $90 \%$ participated in the market directly via shares, other listed investments and self-managed superannuation funds. Given the proportion of these types of investors in the Australian market, complete disclosure of director trading has become increasingly critical. A comprehensive documentation of director trading activity is fundamental if we are to better understand the impact and effect of these activities on many aspects of firm value and trading participation. 


\section{References}

Agrawal, A., \& Nasser, T. (2012). Insider trading in takeover targets. Journal of Corporate Finance, 18(3), 598-625.

Ahmad E., Alireza TR \& Aaron G (2004) Disclosure regulation and the profitability of insider trading: Evidence from New Zealand, Pacific-Basin Finance Journal, 12(5), 479-502.

Aktas, N., De Bodt, E., \& Van Oppens, HAitken, M \& Frino, A. (2008). Legal insider trading and market efficiency. Journal of Banking \& Finance, 32(7), 1379-1392.

Amihud, Y. (2002). Illiquidity and stock returns: cross-section and time-series effects. Journal of financial markets, 5(1), 31-56.Aslan, H. (2002) The Effect of Regulation Fair Disclosure on the Information Environment Working paper, Cornell University.

Ausubel, LM (1990) 'Insider Trading in a Rational Expectations Economy', The American Economic Review, 80(5), 1022-1041.

Barth, ME, Landsman, WR \& Lang, MH (2008) 'International Accounting Standards and Accounting Quality', Journal of Accounting Research, 46(3), 467-498.

Benos, E., \& Jochec, M. (2007). Testing the PIN variable. Available at SSRN 933211.

Beny, L. N. (2005) Do insider trading laws matter? Some preliminary comparative evidence. American Law and Economics Review, 7, (1), 144-183.

Bettis, J. C., Coles, J. L., \& Lemmon, M. L. (2000). Corporate policies restricting trading by insiders. Journal of Financial Economics, 57(2), 191-220

Bhattacharya, U., \& Daouk, H. (2002) The world price of insider trading. Journal of Finance, 57(1), 75-108.

Bollen, N. P., Smith, T., \& Whaley, R. E. (2004). Modeling the bid/ask spread: measuring the inventory-holding premium. Journal of Financial Economics, 72(1), 97-141.

Brochet, F. (2010) Information content of insider trades before and after the Sarbanes-Oxley Act. The Accounting Review, 85(2), 419-446.

Brochet, F., Jagolinzer, A. D., \& Riedl, E. J. (2013) Mandatory IFRS adoption and financial statement comparability. Contemporary Accounting Research, 30(4), 1373-1400.

Brown, P, Foo, M \& Watson, I (2003) 'Trading by Insiders in Australia: Evidence on the Profitability of Directors' Trades', Company and Securities Law Journal, 21(4), 248261.

Brown, P., Taylor, S. L., \& Walter, T. S. (1999). The impact of statutory sanctions on the level and information content of voluntary corporate disclosure. Abacus, 35(2), 138162.

Brunnermeier, M. K., \& Pedersen, L. H. (2009). Market liquidity and funding liquidity. Review of Financial studies, vol 22(6), 2201-2238.

Budsaratragoon, P., Hillier, D., \& Lhaopadchan, S. (2012). Applying developed-country regulation in emerging markets: an analysis of Thai insider trading. Accounting \& Finance, 52(4), 1013-1039.

Bushman, R. M., Piotroki, J. D. \& Smith, A. J. (2005), Insider Trading Restrictions and Analysts' Incentives to Follow Firms. Journal of Finance, 60(1), 35-66.

Cao, C., Field, L. C., \& Hanka, G. (2004). Does insider trading impair market liquidity? Evidence from IPO lockup expirations. Journal of Financial and Quantitative Analysis, 39(1), 25-46.

Carlton, DW \& Fischel, DR (1983) 'The Regulation of Insider Trading', Stanford Law Review, $35(5), 857-895$. 
Chang, M., Hillman, R., \& Watson, I. (2005) Are corporate governance mechanisms effective in reducing insider trading profits. Company and Securities Law Journal, 23(3), 165180.

Chang, M., \& Watson, I. (2015). Delayed disclosure of insider trades: Incentives for and indicators of future performance?. Pacific-Basin Finance Journal, forthcoming.

Chen, Q., Goldstein, I., \& Jiang, W.(2007) Price Informativeness and Investment Sensitivity to Stock Price. Review of Financial Studies, 20(3), 619-650.

Cheng, L, Firth, M, Leung, TY \& Rui, O (2006) 'The Effects of Insider Trading on Liquidity', Pacific-Basin Finance Journal, 14(5), 467-483.

Cheuk, M. Y., Fan, D. K., \& So, R. W. (2006). Insider trading in Hong Kong: Some stylized facts. Pacific-Basin Finance Journal, 14(1), 73-90.

Chung, KH., \& Charoenwong, C (1998) 'Insider Trading and the Bid Ask Spread', Financial Review, 33(3), 1-20.

Clarke, J., \& Shastri, K. (2000). On information asymmetry metrics. Working paper, Georgia Institute of Technology \& University of Pittsburgh.

Copeland, T. E., \& Galai, D. (1983). Information effects on the bid-ask spread. Journal of Finance, 38(5), 1457-1469.

Cornell, B., \& Sirri, E. R. (1992). The reaction of investors and stock prices to insider trading. The Journal of Finance, 47(3), 1031-1059.

Daske, H., Hail, L., Leuz, C., \& Verdi, R. (2008) Mandatory IFRS reporting around the world: Early evidence on the economic consequences. Journal of Accounting Research, 46(5), 1085-1142.

Duarte, J., \& Young, L. (2009). Why is PIN priced?. Journal of Financial Economics, 91(2), $119-138$.

Durnev, A. A., \& Nain, A. S. (2007). Does insider trading regulation deter private information trading? International evidence. Pacific-Basin Finance Journal, 15(5), 409433.

Easley, D., Kiefer, N. M., O'hara, M., \& Paperman, J. B. (1996). Liquidity, information, and infrequently traded stocks. Journal of Finance, 51(4), 1405-1436.

Easley, D., Hvidkjaer, S., \& O'Hara, M. (2002). Is information risk a determinant of asset returns?. Journal of Finance, 57(5), 2185-2221.

Fernandes, N \& Ferreira, M(2009) 'Insider Trading Laws and Stock Price Informativeness', Review of Financial Studies, 22(5), 1845-1887.

Ferreira, D., Ferreira, M.A., \& Raposo, C.C. (2011) Board structure and price informativeness. Journal of Financial Economics, 99(3), 523-545.

Fidrmuc, J. P., Goergen, M \& Renneboog, L (2006) 'Insider Trading, News Releases, and Ownership Concentration', The Journal of Finance, 61(6), 2931-2973.

Fidrmuc, J. P., Korczak, A., \& Korczak, P. (2013) Why does shareholder protection matter for abnormal returns after reported insider purchases and sales?. Journal of Banking \& Finance, 37(6), 1915-1935.

Fishman, MJ \& Hagerty, KM (1992) 'Insider Trading and the Efficiency of Stock Prices', RAND Journal of Economics, 23(1), 106-122.

Friederich, S., Gregory, A., Matatko, J., \& Tonks, I. (2002) Short-run Returns around the Trades of Corporate Insiders on the London Stock Exchange. European Financial Management, 8(1), 7-30.

Frijns, B., Gilbert, A., \& Tourani-Rad, A. (2008) Insider Trading, Regulation, and the Components of the Bid-Ask Spread. Journal of Financial Research, 31(3), 225-246.

Glosten, L. R., \& Milgrom, P. R. (1985) Bid, ask and transaction prices in a specialist market with heterogeneously informed traders. Journal of Financial Economics, 14(1), 71. 
Goyenko, R. Y., Holden, C. W., \& Trzcinka, C. A. (2009). Do liquidity measures measure liquidity?. Journal of Financial Economics, 92(2), 153-181.

Gray, S., Harymawan, I., \& Nowland, J. (2014). Political and government connections on corporate boards in Australia: Good for business?. Australian Journal of Management, forthcoming.

Haggard, K. S., Howe, J. S., \& Lynch, A. A. (2015). Do baths muddy the waters or clear the air?. Journal of Accounting and Economics, 59(1), 105-117.

Hodgson, A \& Van Praag, B (2006) 'Information Trading by Corporate Insiders Based on Accounting Accruals: Forecasting Economic Performance', Accounting \& Finance, 46(5), 819-842.

Hsu, G. C. M., Lindsay, S., \& Tutticci, I. (2012). Inter-temporal changes in analysts' forecast properties under the Australian continuous disclosure regime. Accounting \& Finance, 52(4), 1101-1123.

Huddart, S., Hughes, J. S., \& Levine, C. B. (2001). Public disclosure and dissimulation of insider trades. Econometrica, 69(3), 665-681.

Huddart, S. J., \& Ke, B. (2007). Information Asymmetry and Cross-sectional Variation in Insider Trading. Contemporary Accounting Research, 24(1), 195-232.

Jenter, D. (2005). Market timing and managerial portfolio decisions. Journal of Finance, 60(4), 1903-1949.

Jeanjean, T., \& Stolowy, H. (2008) Do accounting standards matter? An exploratory analysis of earnings management before and after IFRS adoption. Journal of Accounting and Public Policy, 27(6), 480-494.

Kang,Q, \& Liu,Q. (2010) Information-Based Stock Trading, Executive Incentives, and the Principal-Agent Problem. Management Science, 56(4), 682-698.

Ke, B., Huddart, S., \& Petroni, K. (2003) What insiders know about future earnings and how they use it: Evidence from insider trades. Journal of Accounting \& Economics, 35(3), 315-346.

Khan, WA, Baker, HK, Chaudhry, M and Maheshwari, SK(2011) The Impact of Insider Trading on Market Liquidity in the NASDAQ Market, Journal of Applied Business Research, 21(4), 11-22.

Korczak, A., Korczak, P., \& Lasfer, M. (2010). To trade or not to trade: the strategic trading of insiders around news announcements. Journal of Business Finance \& Accounting, 37(3-4), 369-407.

Knewtson, H., \& R. Nofsinger, J. (2014). Why are CFO insider trades more informative?. Managerial Finance, 40(2), 157-175.

Kyle, AS (1985) Continuous Auctions and Insider Trading, Econometrica, 53(6), 1315-1335. Lakonishok, J \& Lee, I (2001) Are Insider Trades Informative?, Review of Financial Studies, 14(1), 79-111.

Lee, C., \& Ready, M. J. (1991). Inferring trade direction from intraday data. Journal of Finance, 46(2), 733-746.

Leland, HE (1992) Insider Trading: Should It Be Prohibited?, Journal of Political Economy, 100(4), 859-887.

Lin, JC \& Howe, JS (1990), Insider Trading in the Otc Market, Journal of Finance, 45(4), 1273-1284.

Llorente, G., Michaely, R., Saar, G., \& Wang, J. (2002). Dynamic volume-return relation of individual stocks. Review of Financial Studies, 15(4), 1005-1047.

Manne, HG (1966), Insider Trading and the Stock Market, New York: The Free Press.

Mohanram, P., \& Rajgopal, S. (2009). Is PIN priced risk?. Journal of Accounting and Economics, 47(3), 226-243. 
Nunn Jr, K. P., Madden, G. P., \& Gombola, M. J. (1983). Are some insiders more "inside" than others?. The Journal of Portfolio Management, 9(3), 18-22.

Piotroski, JD \& Roulstone, BT (2004), The Influence of Analysts, Institutional Investors, and Insiders on the Incorporation of Market, Industry, and Firm-Specific Information into Stock Prices, Accounting Review, 79(4), 1119-1151.

Piotroski, J. D., \& Roulstone, D. T. (2005). Do insider trades reflect both contrarian beliefs and superior knowledge about future cash flow realizations?. Journal of Accounting and Economics, 39(1), 55-81.

Piotroski, J. D., \& Roulstone, D. T. (2007). Evidence on the non-linear relation between insider trading decisions and future earnings information. JL Econ. \& Pol'y, 4, 409.

Ravina, E., \& Sapienza, P. (2010). What do independent directors know? Evidence from their trading. Review of Financial Studies, 23(3), 962-1003.

Rogers, J. L. (2008). Disclosure quality and management trading incentives. Journal of

Accounting Research, 46(5), 1265-1296.Seyhun, HN (1986), 'Insiders' Profits, Costs of

Trading, and Market Efficiency', Journal of Financial Economics, 16(2), 189-212.

Seyhun, HN. (1988). The information content of aggregate insider trading. Journal of Business 61(1), 1-24.

Seyhun, HN. (1992). Why does aggregate insider trading predict future stock returns? The Quarterly Journal of Economics, 107(4), 1303-1331.

Sidhu, B., Smith, T., Whaley, R. E., \& Willis, R. H. (2008). Regulation Fair Disclosure and the cost of adverse selection. Journal of Accounting Research, 46(3), 697-728.

Straser, V. (2002). Regulation Fair Disclosure and information asymmetry. Working paper, University of Notre Dame. 


\section{Table 1 Summary Statistics}

This table presents the summary statistics of all the variables employed in this study. The summary statistics include mean value (Mean), median value (Median), standard deviation (StdDev), 5th percentile (P5) and 95th percentile (P95), minimum value (Min) and maximum value (Max). Adverse is the average of daily adverse selection costs in the event window $[0,120]$ where day 0 is the date of the insider transaction. PIN is the probability of informed trading (PIN) measure by Easley, Kiefer, O'Hara and Paperman (1996) estimated in the event window [0,120]. adjAdverse is the average of daily adverse selection costs in the event window [0,120] where day 0 is the date of the insider transaction, scaled by daily average adverse selection costs computed over the window [-120, -21] relative to the insider transaction date. adjPIN is the PIN variable estimated in the window $[0,120]$ scaled by the PIN measure estimated in the estimation window [-120, -21] relative to the insider trading transaction. $C A R$ is the cumulative market-adjusted stock return over the event window [0, 120]. Turnover is the log of number of shares traded in the previous year. Volatility is the $\log$ of standard deviation of daily stock returns in the previous year. $B M$ is the book-to-market ratio calculated as the book value of equity divided by the market value of equity. Size is equal to $\log$ of market value of equity. Resource is a dummy variable which takes the value of one if the firm operates in resources industry, and zero otherwise. Financial is a dummy variable which takes the value of one if a firm operates in financial industry, and zero otherwise. All variables are winsorised at the top and bottom $1 \%$ of the distribution. The number of insider trades with non-missing variables is 17,676 . The sample period is from 2002 to 2010 .

\begin{tabular}{lrrrrrrr}
\hline \hline & \multicolumn{1}{c}{ Mean } & Median & \multicolumn{1}{l}{ Std } & \multicolumn{1}{l}{ P5 } & \multicolumn{1}{l}{ P95 } & \multicolumn{1}{l}{ Min } & \multicolumn{1}{l}{ Max } \\
\hline Adverse & 0.0024 & 0.0018 & 0.0020 & 0.0005 & 0.0065 & 0.0003 & 0.0106 \\
PIN & 0.1818 & 0.1715 & 0.0910 & 0.0228 & 0.3390 & 0.0005 & 0.4678 \\
adjAdverse & 1.0237 & 0.9710 & 0.3390 & 0.5796 & 1.6722 & 0.4223 & 2.3959 \\
adjPIN & 3.3624 & 0.9810 & 15.0426 & 0.2518 & 2.6058 & 0.0037 & 125.8103 \\
CAR & 0.0242 & 0.0178 & 0.2076 & -0.2968 & 0.3686 & -0.6131 & 0.7440 \\
Turnover & 5.5450 & 5.6963 & 1.4528 & 3.0908 & 7.6976 & 2.2459 & 8.5119 \\
Volatility & 0.0212 & 0.0182 & 0.0102 & 0.0097 & 0.0427 & 0.0079 & 0.0576 \\
BM & 0.5743 & 0.4925 & 0.3785 & 0.1409 & 1.3312 & 0.0721 & 2.0625 \\
Size & 21.3932 & 21.2669 & 1.6449 & 18.9211 & 24.4431 & 18.1249 & 24.8658 \\
Resource & 0.1714 & 0.0000 & 0.3769 & 0.0000 & 1.0000 & 0.0000 & 1.0000 \\
Financials & 0.2559 & 0.0000 & 0.4364 & 0.0000 & 1.0000 & 0.0000 & 1.0000 \\
\hline \hline
\end{tabular}




\section{Table 2 Pearson Correlation Coefficients}

This table presents the Pearson correlation coefficients among all the variables employed in this study. adjAdverse is the average of daily adverse selection costs in the event window $[0,120]$ where day 0 is the date of the insider transaction, scaled by daily average adverse selection costs computed over the window $[-120,-21]$ relative to the insider transaction date. adjPIN is the PIN variable estimated in the window $[0,120]$ scaled by the PIN measure estimated in the estimation window [-120, -21] relative to the insider trading transaction. CAR is the cumulative market-adjusted stock return over the event window $[0,120]$. Turnover is the log of number of shares traded in the previous year. Volatility is the log of standard deviation of daily stock returns in the previous year. BM is the bookto-market ratio calculated as the book value of equity divided by the market value of equity. Size is equal to log of market value of equity. Resource is a dummy variable which takes the value of one if the firm operates in resources industry, and zero otherwise. Financial is a dummy variable which takes the value of one if a firm operates in financial industry, and zero otherwise. All variables are winsorised at the top and bottom $1 \%$ of the distribution. The $p$-values are shown in the parentheses. The number of insider trades with non-missing variables is 17,676 . The sample period is from 2002 to 2010.

\begin{tabular}{|c|c|c|c|c|c|c|c|c|c|}
\hline & adjAdverse & adjPin & $C A R$ & Turnover & Volatility & $B M$ & Size & Resource & Financials \\
\hline adjAdverse & 1.000 & & & & & & & & \\
\hline adjPIN & $\begin{array}{l}0.011 \\
(0.13)\end{array}$ & 1.000 & & & & & & & \\
\hline$C A R$ & $\begin{array}{r}-0.103 \\
(0.00)\end{array}$ & $\begin{array}{l}0.026 \\
(0.00)\end{array}$ & 1.000 & & & & & & \\
\hline Turnover & $\begin{array}{l}0.016 \\
(0.04)\end{array}$ & $\begin{array}{l}0.033 \\
(0.00)\end{array}$ & $\begin{array}{c}-0.028 \\
(0.00)\end{array}$ & 1.000 & & & & & \\
\hline Volatility & $\begin{array}{l}0.210 \\
(0.00)\end{array}$ & $\begin{array}{l}0.011 \\
(0.15)\end{array}$ & $\begin{array}{l}0.066 \\
(0.00)\end{array}$ & $\begin{array}{r}-0.049 \\
(0.00)\end{array}$ & 1.000 & & & & \\
\hline$B M$ & $\begin{array}{l}0.092 \\
(0.00)\end{array}$ & $\begin{array}{r}-0.016 \\
(0.04)\end{array}$ & $\begin{array}{l}0.000 \\
(0.95)\end{array}$ & $\begin{array}{r}-0.037 \\
(0.00)\end{array}$ & $\begin{array}{l}0.228 \\
(0.00)\end{array}$ & 1.000 & & & \\
\hline Size & $\begin{array}{r}-0.032 \\
(0.00)\end{array}$ & $\begin{array}{l}0.026 \\
(0.00)\end{array}$ & $\begin{array}{r}-0.045 \\
(0.00)\end{array}$ & $\begin{array}{l}0.711 \\
(0.00)\end{array}$ & $\begin{array}{r}-0.361 \\
(0.00)\end{array}$ & $\begin{array}{c}-0.334 \\
(0.00)\end{array}$ & 1.000 & & \\
\hline Resource & $\begin{array}{r}-0.052 \\
(0.00)\end{array}$ & $\begin{array}{l}0.010 \\
(0.21)\end{array}$ & $\begin{array}{l}0.069 \\
(0.00)\end{array}$ & $\begin{array}{l}0.129 \\
(0.00)\end{array}$ & $\begin{array}{l}0.307 \\
(0.00)\end{array}$ & $\begin{array}{r}-0.087 \\
(0.00)\end{array}$ & $\begin{array}{l}-0.010 \\
(0.18)\end{array}$ & 1.000 & \\
\hline Financials & $\begin{array}{r}-0.002 \\
(0.74)\end{array}$ & $\begin{array}{r}-0.009 \\
(0.22)\end{array}$ & $\begin{array}{r}-0.049 \\
(0.00)\end{array}$ & $\begin{array}{l}0.096 \\
(0.00)\end{array}$ & $\begin{array}{r}-0.223 \\
(0.00)\end{array}$ & $\begin{array}{l}0.042 \\
(0.00)\end{array}$ & $\begin{array}{l}0.321 \\
(0.00)\end{array}$ & $\begin{array}{r}-0.267 \\
(0.00)\end{array}$ & 1.000 \\
\hline
\end{tabular}




\section{Table 3 Effects of Insider Trading Profitability on Information Asymmetry}

This table presents the regression results of the stock trading information proxy, adjAdverse, on the information content of insider trades measure, $C A R$, together with other control variables. adjAdverse is the average of daily adverse selection costs in the event window $[0,120]$ where day 0 is the date of the insider transaction, scaled by daily average adverse selection costs computed over the window $[-120,-21]$ relative to the insider transaction date. CAR is the cumulative market-adjusted stock return over the event window $[0,120]$. Turnover is the log of number of shares traded in the previous year. Volatility is the log of standard deviation of daily stock returns in the previous year. $B M$ is the book-to-market ratio calculated as the book value of equity divided by the market value of equity. Size is equal to log of market value of equity. Resource is a dummy variable which takes the value of one if the firm operates in resources industry, and zero otherwise. Financial is a dummy variable which takes the value of one if a firm operates in financial industry, and zero otherwise. All variables are winsorised at the top and bottom $1 \%$ of the distribution. The $t$-values based on the standard errors adjusted for firm-level clustering are reported in the parentheses. NObs is the number of observations. Adj. R2 is the adjusted R-squared. The sample period is from 2002 to 2010.

\begin{tabular}{lccc}
\hline \hline & $(1)$ & $(2)$ & $(3)$ \\
\hline Intercept & 1.028 & 0.421 & 0.868 \\
& $(142.03)$ & $(2.95)$ & $(5.40)$ \\
CAR & -0.168 & -0.178 & -0.133 \\
& $(-4.24)$ & $(-4.71)$ & $(-4.41)$ \\
Turnover & & -0.006 & 0.015 \\
& & $(-0.71)$ & $(2.13)$ \\
Volatility & & 9.140 & 5.094 \\
& & $(8.85)$ & $(3.57)$ \\
BM & & 0.046 & 0.079 \\
& & $(1.67)$ & $(3.15)$ \\
Size & & 0.021 & 0.005 \\
& & $(2.70)$ & $(0.62)$ \\
Resource & & -0.111 & -0.080 \\
& & $(-6.07)$ & $(-5.01)$ \\
Financials & & -0.009 & -0.009 \\
& & $(-0.50)$ & $(-0.66)$ \\
Year FE & No & No & Yes \\
NObs & 17,676 & 17,676 & 17,676 \\
Adj. R2 & $1.0 \%$ & $7.6 \%$ & $28.8 \%$ \\
\hline \hline
\end{tabular}




\section{Table 4 Effects of Insider Trading Profitability on Stock Price Informativeness}

This table presents the regression results of the stock trading information proxy, adjPIN, on the information content of insider trades measure, $C A R$, together with other control variables. adjPIN is the PIN variable estimated in the window $[0,120]$ scaled by the PIN measure estimated in the estimation window $[-120,-21]$ relative to the insider trading transaction.. CAR is the cumulative market-adjusted stock return over the event window [0,120]. Turnover is the log of number of shares traded in the previous year. Volatility is the log of standard deviation of daily stock returns in the previous year. $B M$ is the book-to-market ratio calculated as the book value of equity divided by the market value of equity. Size is equal to log of market value of equity. Resource is a dummy variable which takes the value of one if the firm operates in resources industry, and zero otherwise. Financial is a dummy variable which takes the value of one if a firm operates in financial industry, and zero otherwise. All variables are winsorised at the top and bottom $1 \%$ of the distribution. The $t$-values based on the standard errors adjusted for firm-level clustering are reported in the parentheses. NObs is the number of observations. Adj. $R 2$ is the adjusted R-squared. The sample period is from 2002 to 2010.

\begin{tabular}{lccc}
\hline \hline & $(1)$ & $(2)$ & $(3)$ \\
\hline Intercept & 3.316 & -0.958 & 1.324 \\
& $(10.98)$ & $(-0.20)$ & $(0.25)$ \\
CAR & 1.890 & 1.882 & 1.893 \\
& $(2.02)$ & $(2.01)$ & $(2.13)$ \\
Turnover & & 0.269 & 0.339 \\
& & $(0.83)$ & $(1.07)$ \\
Volatility & & 25.926 & 4.798 \\
& & $(0.83)$ & $(0.11)$ \\
BM & & -0.563 & -0.686 \\
& & $(-0.87)$ & $(-1.01)$ \\
Size & & 0.126 & 0.058 \\
& & $(0.48)$ & $(0.21)$ \\
Resource & & -0.209 & -0.029 \\
& & $(-0.26)$ & $(-0.04)$ \\
Financials & & -0.400 & -0.399 \\
& & $(-0.52)$ & $(-0.52)$ \\
Year FE & No & No & Yes \\
NObs & 17,525 & 17,525 & 17,525 \\
Adj. R2 & $0.1 \%$ & $0.2 \%$ & $0.5 \%$ \\
\hline \hline
\end{tabular}


Table 5 Effects of Insider Purchases and Sales on Stock Trading Information Environment

This table presents the regression results of two stock trading information proxies, adjAdverse and adjPIN, on the information content of insider trades measure, CAR, together with other control variables. Year dummies are also included in all the estimation models. Models (1) and (3) report results based on the subsample of insider purchases while Models (2) and (4) estimate the regression models on the subsample of insider sell. adjAdverse is the average of daily adverse selection costs in the event window $[0,120]$ where day 0 is the date of the insider transaction, scaled by daily average adverse selection costs computed over the window [-120, 21] relative to the insider transaction date. adjPIN is the PIN variable estimated in the window [0, 120] scaled by the PIN measure estimated in the estimation window [-120, -21] relative to the insider trading transaction. CAR is the cumulative market-adjusted stock return over the event window [0, 120]. Turnover is the log of number of shares traded in the previous year. Volatility is the $\log$ of standard deviation of daily stock returns in the previous year. $B M$ is the book-to-market ratio calculated as the book value of equity divided by the market value of equity. Size is equal to $\log$ of market value of equity. Resource is a dummy variable which takes the value of one if the firm operates in resources industry, and zero otherwise. Financial is a dummy variable which takes the value of one if a firm operates in financial industry, and zero otherwise. All variables are winsorised at the top and bottom $1 \%$ of the distribution. The $t$-values based on the standard errors adjusted for firm-level clustering are reported in the parentheses. $N O b s$ is the number of observations. Adj. R2 is the adjusted R-squared. The sample period is from 2002 to 2010.

\begin{tabular}{|c|c|c|c|c|}
\hline & \multicolumn{2}{|c|}{ adjAdverse } & \multicolumn{2}{|c|}{ adjPIN } \\
\hline & Purchase & Sell & Purchase & Sell \\
\hline & (1) & $(2)$ & (3) & (4) \\
\hline \multirow[t]{2}{*}{ Intercept } & 0.800 & 1.245 & 4.127 & -19.862 \\
\hline & (4.68) & $(6.43)$ & $(0.70)$ & $(-2.34)$ \\
\hline \multirow[t]{2}{*}{$C A R$} & -0.191 & 0.235 & 1.865 & 0.659 \\
\hline & $(-5.46)$ & $(4.28)$ & (1.88) & $(0.45)$ \\
\hline \multirow[t]{2}{*}{ Turnover } & 0.014 & 0.025 & 0.424 & -0.256 \\
\hline & (1.78) & $(2.62)$ & $(1.21)$ & $(-0.64)$ \\
\hline \multirow[t]{2}{*}{ Volatility } & 6.358 & 0.287 & -15.019 & 191.956 \\
\hline & $(4.22)$ & $(0.16)$ & $(-0.34)$ & $(1.95)$ \\
\hline \multirow[t]{2}{*}{$B M$} & 0.071 & 0.074 & -0.795 & 0.822 \\
\hline & (2.67) & $(2.07)$ & $(-1.04)$ & $(0.68)$ \\
\hline \multirow[t]{2}{*}{ Size } & 0.007 & -0.009 & -0.070 & 0.965 \\
\hline & (0.89) & $(-1.01)$ & $(-0.23)$ & $(2.54)$ \\
\hline \multirow[t]{2}{*}{ Resource } & -0.082 & -0.069 & 0.121 & -2.049 \\
\hline & $(-4.68)$ & $(-3.06)$ & $(0.13)$ & $(-1.99)$ \\
\hline \multirow[t]{2}{*}{ Financials } & -0.010 & -0.013 & -0.299 & -0.819 \\
\hline & $(-0.69)$ & $(-0.61)$ & $(-0.36)$ & $(-0.89)$ \\
\hline Year FE & Yes & Yes & Yes & Yes \\
\hline NObs & 15,396 & 2,899 & 15,263 & 2,874 \\
\hline Adj. R2 & $29.7 \%$ & $27.5 \%$ & $0.5 \%$ & $1.2 \%$ \\
\hline
\end{tabular}




\section{Table 6 Effects of Executives' and Non-executives' Trading Profitability on Stock}

Trading Information Environment

This table presents the regression results of two stock trading information proxies, adjAdverse and adjPIN, on the information content of insider trades measure, CAR, together with other control variables. Year dummies are also included in all the estimation models. Models (1) and (3) report results based on the subsample of insider trades executed by corporate executives while Models (2) and (4) estimate the regression models on the subsample of insider purchases executed by non-executive directors. adjAdverse is the average of daily adverse selection costs in the event window $[0,120]$ where day 0 is the date of the insider transaction, scaled by daily average adverse selection costs computed over the window [-120, -21] relative to the insider transaction date. adjPIN is the PIN variable estimated in the window $[0,120]$ scaled by the PIN measure estimated in the estimation window [-120, -21] relative to the insider trading transaction. $C A R$ is the cumulative market-adjusted stock return over the event window [0, 120]. Turnover is the $\log$ of number of shares traded in the previous year. Volatility is the $\log$ of standard deviation of daily stock returns in the previous year. $B M$ is the book-to-market ratio calculated as the book value of equity divided by the market value of equity. Size is equal to $\log$ of market value of equity. Resource is a dummy variable which takes the value of one if the firm operates in resources industry, and zero otherwise. Financial is a dummy variable which takes the value of one if a firm operates in financial industry, and zero otherwise. All variables are winsorised at the top and bottom $1 \%$ of the distribution. The $t$-values based on the standard errors adjusted for firm-level clustering are reported in the parentheses. $N O b s$ is the number of observations. Adj. R2 is the adjusted R-squared. The sample period is from 2002 to 2010.

\begin{tabular}{|c|c|c|c|c|}
\hline & \multicolumn{2}{|c|}{ adjAdverse } & \multicolumn{2}{|c|}{ adjPIN } \\
\hline & Executives & $\begin{array}{c}\text { Non- } \\
\text { Executives }\end{array}$ & Executives & $\begin{array}{c}\text { Non- } \\
\text { executives }\end{array}$ \\
\hline & (1) & $(2)$ & (3) & (4) \\
\hline \multirow[t]{2}{*}{ Intercept } & 0.679 & 0.891 & -8.356 & 6.481 \\
\hline & $(2.53)$ & $(4.85)$ & $(-1.29)$ & $(0.94)$ \\
\hline \multirow[t]{2}{*}{$C A R$} & -0.091 & -0.157 & 1.947 & 1.860 \\
\hline & $(-2.24)$ & $(-4.42)$ & (1.54) & (1.86) \\
\hline \multirow[t]{2}{*}{ Turnover } & 0.017 & 0.015 & 0.193 & 0.456 \\
\hline & (1.40) & (1.89) & $(0.46)$ & $(1.17)$ \\
\hline \multirow[t]{2}{*}{ Volatility } & 6.885 & 4.956 & 49.754 & -13.513 \\
\hline & $(2.76)$ & (3.18) & $(0.95)$ & $(-0.24)$ \\
\hline \multirow[t]{2}{*}{$B M$} & 0.067 & 0.083 & 0.596 & -1.360 \\
\hline & (1.84) & $(2.90)$ & $(0.91)$ & $(-1.60)$ \\
\hline \multirow[t]{2}{*}{ Size } & 0.013 & 0.003 & 0.416 & -0.150 \\
\hline & (1.06) & $(0.40)$ & (1.18) & $(-0.42)$ \\
\hline \multirow[t]{2}{*}{ Resource } & -0.097 & -0.077 & 0.912 & -0.343 \\
\hline & $(-3.78)$ & $(-4.46)$ & $(0.79)$ & $(-0.33)$ \\
\hline \multirow[t]{2}{*}{ Financials } & -0.013 & -0.006 & -0.112 & -0.394 \\
\hline & $(-0.60)$ & $(-0.41)$ & $(-0.12)$ & $(-0.43)$ \\
\hline Year FE & Yes & Yes & Yes & Yes \\
\hline$N O b s$ & 4,407 & 11,882 & 4,375 & 11,779 \\
\hline Adj. R2 & $30.0 \%$ & $28.6 \%$ & $0.4 \%$ & $0.7 \%$ \\
\hline
\end{tabular}




\section{Table 7 Robustness Tests}

This table presents two sets of robustness tests on the main results. In Models (1) and (2), we use adjAdverse 240 and adjPIN240 as the dependent variables, where adjAdverse 240 is the daily average adverse selection cost computed in the window [121, 240], scaled by the daily average adverse selection cost computed in the estimation window [-120, -21]; and adjPIN240 is the PIN variable estimated in the window [121, 240] scaled by the PIN measure estimated in the estimation window [-120, -21] relative to the insider trading transaction. In Models (3) and (4), we use an alternative measure of insider trading profitability, BHAR, which is computed as the buy-and-hold market-adjusted stock returns in the window [0, 120]. Year dummies are also included in all the estimation models. adjAdverse is the average of daily adverse selection costs in the event window [0, 120] where day 0 is the date of the insider transaction, scaled by daily average adverse selection costs computed over the window $[-120,-21]$ relative to the insider transaction date. adjPIN is the PIN variable estimated in the window [0,120] scaled by the PIN measure estimated in the estimation window [-120, -21] relative to the insider trading transaction. $C A R$ is the cumulative market-adjusted stock return over the event window [0, 120]. IFRS is a dummy variable which equals one if the observation is on or after fiscal year 2005, and zero otherwise. $G F C$ is a dummy variable which equals one if the observation is on or after year 2008, and zero otherwise. Turnover is the log of number of shares traded in the previous year. Volatility is the log of standard deviation of daily stock returns in the previous year. $B M$ is the book-to-market ratio calculated as the book value of equity divided by the market value of equity. Size is equal to $\log$ of market value of equity. Resource is a dummy variable which takes the value of one if the firm operates in resources industry, and zero otherwise. Financial is a dummy variable which takes the value of one if a firm operates in financial industry, and zero otherwise. All variables are winsorised at the top and bottom $1 \%$ of the distribution. The $t$-values based on the standard errors adjusted for firm-level clustering are reported in the parentheses. NObs is the number of observations. Adj. R2 is the adjusted R-squared. The sample period is from 2002 to 2010.

\begin{tabular}{lcccc}
\hline \hline & AdjAdverse240 & AdjPIN240 & AdjAdverse & AdjPIN \\
\cline { 2 - 5 } Intercept & $(1)$ & $(2)$ & $(3)$ & $(4)$ \\
CAR & 1.295 & 1.503 & 0.871 & 1.284 \\
& $(5.78)$ & $(0.24)$ & $(5.44)$ & $(0.24)$ \\
BHAR & -0.309 & 1.873 & & \\
& $(-7.56)$ & $(1.80)$ & & \\
Turnover & & & -0.138 & 1.830 \\
& & & $(-5.11)$ & $(2.04)$ \\
Volatility & 0.033 & 0.460 & 0.015 & 0.341 \\
& $(3.00)$ & $(1.13)$ & $(2.11)$ & $(1.08)$ \\
BM & 3.738 & -11.834 & 5.088 & 5.020 \\
& $(1.79)$ & $(-0.25)$ & $(3.57)$ & $(0.11)$ \\
Size & 0.094 & -0.394 & 0.078 & -0.672 \\
& $(3.05)$ & $(-0.48)$ & $(3.11)$ & $(-0.99)$ \\
Resource & -0.017 & 0.053 & 0.005 & 0.059 \\
Financials & $(-1.59)$ & $(0.16)$ & $(0.61)$ & $(0.22)$ \\
& -0.113 & -0.033 & -0.079 & -0.037 \\
Year FE & $(-4.83)$ & $(-0.03)$ & $(-4.97)$ & $(-0.05)$ \\
NObs & 0.004 & -0.507 & -0.009 & -0.396 \\
Adj R2 & $(0.19)$ & $(-0.56)$ & $(-0.69)$ & $(-0.52)$ \\
\hline \hline
\end{tabular}




\section{Table 8 Effects of IFRS adoption and Global Financial Crisis on the Relationship between Insider Trading Profitability and Stock Trading Information Environment}

This table presents the regression results of two stock trading information proxies, adjAdverse and adjPIN, on the information content of insider trades measure, CAR, and its interactions with the IFRS adoption and GFC dummy variables, together with other control variables. Year dummies are also included in all the estimation models. adjAdverse is the average of daily adverse selection costs in the event window [0,120] where day 0 is the date of the insider transaction, scaled by daily average adverse selection costs computed over the window [$120,-21]$ relative to the insider transaction date. adjPIN is the PIN variable estimated in the window [0, 120] scaled by the PIN measure estimated in the estimation window [-120, -21] relative to the insider trading transaction. $C A R$ is the cumulative market-adjusted stock return over the event window [0, 120]. IFRS is a dummy variable which equals one if the observation is on or after fiscal year 2005, and zero otherwise. GFC is a dummy variable which equals one if the observation is on or after year 2008, and zero otherwise. Turnover is the log of number of shares traded in the previous year. Volatility is the log of standard deviation of daily stock returns in the previous year. $B M$ is the book-to-market ratio calculated as the book value of equity divided by the market value of equity. Size is equal to log of market value of equity. Resource is a dummy variable which takes the value of one if the firm operates in resources industry, and zero otherwise. Financial is a dummy variable which takes the value of one if a firm operates in financial industry, and zero otherwise. All variables are winsorised at the top and bottom $1 \%$ of the distribution. The $t$-values based on the standard errors adjusted for firm-level clustering are reported in the parentheses. NObs is the number of observations. Adj. R2 is the adjusted R-squared. The sample period is from 2002 to 2010.

\begin{tabular}{|c|c|c|c|c|}
\hline & \multicolumn{2}{|c|}{ adjAdverse } & \multicolumn{2}{|c|}{ adjPIN } \\
\hline & (1) & $(2)$ & (3) & (4) \\
\hline \multirow[t]{2}{*}{ Intercept } & 0.354 & 0.174 & -0.924 & -0.410 \\
\hline & $(2.54)$ & (1.18) & $(-0.19)$ & $(-0.09)$ \\
\hline \multirow[t]{2}{*}{$C A R$} & -0.178 & -0.160 & 3.868 & 3.268 \\
\hline & $(-2.94)$ & $(-3.64)$ & (1.57) & $(2.45)$ \\
\hline \multirow[t]{2}{*}{$I F R S$} & -0.083 & & 0.262 & \\
\hline & $(-5.68)$ & & $(0.49)$ & \\
\hline \multirow[t]{2}{*}{$I F R S^{*} C A R$} & -0.008 & & -2.492 & \\
\hline & $(-0.11)$ & & $(-0.91)$ & \\
\hline \multirow[t]{2}{*}{$G F C$} & & -0.096 & & 0.264 \\
\hline & & $(-4.40)$ & & $(0.34)$ \\
\hline \multirow[t]{2}{*}{$G F C * C A R$} & & -0.039 & & -3.139 \\
\hline & & $(-0.60)$ & & $(-1.62)$ \\
\hline \multirow[t]{2}{*}{ Turnover } & -0.004 & -0.009 & 0.263 & 0.282 \\
\hline & $(-0.45)$ & $(-1.03)$ & $(0.81)$ & $(0.88)$ \\
\hline \multirow[t]{2}{*}{ Volatility } & 10.586 & 11.947 & 23.251 & 22.100 \\
\hline & (10.09) & $(9.27)$ & $(0.75)$ & $(0.69)$ \\
\hline \multirow[t]{2}{*}{$B M$} & 0.040 & 0.071 & -0.562 & -0.655 \\
\hline & $(1.44)$ & $(2.75)$ & $(-0.87)$ & $(-0.96)$ \\
\hline \multirow[t]{2}{*}{ Size } & 0.025 & 0.031 & 0.120 & 0.100 \\
\hline & (3.32) & (3.94) & $(0.46)$ & $(0.38)$ \\
\hline \multirow[t]{2}{*}{ Resource } & -0.114 & -0.120 & -0.211 & -0.229 \\
\hline & $(-6.28)$ & $(-6.27)$ & $(-0.26)$ & $(-0.28)$ \\
\hline \multirow[t]{2}{*}{ Financials } & -0.013 & -0.014 & -0.398 & -0.373 \\
\hline & $(-0.76)$ & $(-0.78)$ & $(-0.52)$ & $(-0.48)$ \\
\hline Year FE & Yes & Yes & Yes & Yes \\
\hline Nobs & 17,676 & 17,676 & 17,525 & 17,525 \\
\hline Adj. R2 & $8.8 \%$ & $8.5 \%$ & $0.2 \%$ & $0.2 \%$ \\
\hline
\end{tabular}

